Research Article

Open Access

\title{
Polymorphism of 8-Oxoguanine DNA N-Glycosylase 1 Gene in Egyptian patients with Larynx Cancer
}

\author{
Amal Helmy Abd Elhameed ${ }^{1 *}$, Tawfik HA ${ }^{2}$, Ibrahim WS ${ }^{3}$ and El-Kabbany SM ${ }^{4}$ \\ IProfessor, Department of Clinical Pathology, Faculty of medicine, Tanta University, Egypt \\ 2 Professor, Department of Tropical Medicine, Faculty of medicine, Tanta University, Egypt \\ ${ }^{3}$ Assistant Professor, Department of Clinical Pathology, Faculty of medicine, Tanta University, Egypt \\ ${ }^{4} \mathrm{PhD}$ Student
}

\section{Article Info}

\author{
*Corresponding author: \\ Amal Helmy Abd Elhameed \\ Professor \\ Clinical Pathology department \\ Faculty of medicine \\ Tanta University \\ Egypt \\ Tel: 01001856164 \\ E-mail: amalhelmy2015@gmail.com
}

Received: October 16, 2017

Accepted: November 10, 2017

Published: November 16, 2017

Citation: Abd Elhameed $\mathrm{AH}$, Tawfik HA, Ibrahim WS, El-Kabbany SM. Polymorphism of 8-Oxoguanine DNA N-Glycosylase 1 Gene in Egyptian patients with Larynx Cancer. Madridge J Oncogenesis. 2017; 1(1): 8-11. doi: 10.18689/mjo-1000102

Copyright: (c) 2017 The Author(s). This work is licensed under a Creative Commons Attribution 4.0 International License, which permits unrestricted use, distribution, and reproduction in any medium, provided the original work is properly cited.

Published by Madridge Publishers

\begin{abstract}
Objective: To investigate the human 8-Oxoguanine DNAN-Glycosylase 1 gene polymorphism susceptibility in Egyptian patients with cancer larynx.
\end{abstract}

Methods: DNA samples from 240 patients with larynx cancer and 240 age-matched controls were genotyped using a PCR-RFLP.

Results: The frequencies of the genotypes were Ser/Ser89\%, Ser/Cys9\%, and Cys/Cys2\% in the controls, and in patients were $58 \%, 32.9 \%$ and $9.1 \%$, respectively. The Ser/Cys and Cys/Cys genotypes were significantly associated with the increased risk of cancer larynx and these genotypes increased the risk percent of larynx cancer among moderate and heavy smokers.

Conclusion: The Ser/Cys and Cys/Cys genotypes are significantly associated with the increased risk of larynx cancer in Egyptian population.

Keywords: hOGG1; Polymorphism; Ser326Cys; Larynx cancer.

\section{Introduction}

Carcinoma of the larynx forms an important group of malignancies as it accounts for approximately $1 \%$ of new cancer diagnosis [1]. The highest incidence rates have been registered in more developed countries of the world and the lowest in the developing countries. In Egypt, laryngeal cancer is considered the most common head and neck cancer because cigarette smoking, an indisputable risk factor, is on the rise in the community [2].

The incidence of laryngeal cancer in Kasr El-Aini Center of Radiation Oncology and Nuclear Medicine, Faculty of Medicine, Cairo University is 3.1\% per year. Advanced laryngeal cancer is generally considered as the disease in stages III and IV based on the primary tumor extension and/or the presence of metastatic lymph node(s) in the neck and it accounts for roughly $40 \%$ to $50 \%$ of patients with laryngeal cancer [3].

A variety of genes can be involved in the multi-stage process of carcinogenesis, including oncogenes and suppress or genes, genes involved in the metabolism of carcinogen, DNA repair genes [4]. The human 8-oxoguanine DNA N-glycosylase 1 (hOGG1) gene maps to 3p26chromosome and expresses two major mRNAs encoding proteins composed of 345 and 424 amino acid residues ( $\alpha$-hoGG1 and $\beta$-hoGG1, respectively) [5].

8-Oxoguanine is a major form of mutagenic base damage caused by reactive oxygen species (ROS) and is a hallmark and marker of oxidative damage to DNA. This lesion is recognized by the hOGGI protein, which is a glycosylase of DNA base excision repair (BER) 
pathway. It has an endo-nuclease activity allowing it to excise oxidized base from DNA [6].

Because malignant tumors often show an increased level of oxidation of the DNA bases, this may suggest the implication of oxidative DNA damage in the etiology of at least some cancers [4]. It seems that this be the case of fraction of head and neck cancers (HNCs), in which smoking is involved in their pathogenesis, because tobacco smoking products can induce (ROS) [7].

The human OGG1 gene is located on chromosome 3 (3p26), and encodes a bifunctional DNA glycosylase endowed with an AP lyase activity. This is a region frequently lost in various types of cancers. Loss of the gene would abrogate OGG1 activity imposing an increased risk of mutagenicity on the cell due to accumulation of 8-oxoG in DNA. A common polymorphism of this gene, Ser326Cys a $C \rightarrow G$ polymorphism in codon 326 at exon 7 is associated with an increased risk of cancer [8].

It was suggested that the Ser326Cys polymorphism of the hOGG1 gene might play an important role in risk for smoking and alcohol-related cancers of the aero digestive tract, including HNCs $[9,10]$. This study aimed to investigate the association of the variability in the hOGG1genepolymorphism, and there is k of larynx cancer in Egyptian patients.

\section{Subjects and Methods}

Blood samples were obtained from 240 patients (192 men and 48 women) with histological confirmed laryngeal carcinoma aged from 46 to 82 years. Patients were selected from Clinical Oncology Department of Tanta University Hospitals, Egypt, and 240 normal healthy controls were matched by age, gender and geographic origin with the patients group from June 2015 to September 2017.The study was approved by the Ethical Committee of Tanta University, and a written informed consent was obtained from all participants.

Complete personal and family history, smoking, clinical examination and routine laboratory investigations $(C B C, E S R$, LFT and KFT) were performed. Genotyping of the hOGG1 gene was performed by PCR/RFLP. All investigations were done in Clinical Pathology Department, Faculty of medicine, Tanta University, Egypt.

\section{DNA isolation}

Peripheral blood lymphocytes (PBLs) were isolated by centrifugation in a density gradient of $15 \mathrm{~min}, 280 \mathrm{~g}$. The pellet containing PBLs was re-suspended in Tris-EDTA buffer, $\mathrm{pH} 8$, to give $1-3 \times 10^{3}$ cells/ml. Genomic DNA was extracted from PBLs by phenol/chloroform extraction and proteinase $\mathrm{K}$ digestion. The final samples were kept in Tris-EDTA buffer, $\mathrm{pH}$ 8 , at $-20^{\circ} \mathrm{C}$ until use.

\section{Genotype determination}

The genotypes of the Ser326Cys polymorphism of the hOGG1 gene were determined by restriction fragment length polymorphism polymerase chain reaction (PCR) with the following primers: sense5'-GGAAGGTGCTTGGGGAAT-3', ntisense 5'- ACTGTCACTAGTCTCACCAG -3'. Individual PCR reaction were Performed in a total volume of $25 \mu$ using 10 ng of genomic DNA, $0.4 \mu \mathrm{Mol}$ of oligonucleotide primer specific for hOGG1 gene (exon 7), 0.2m Mol dNTPs (dATP, dCTP, dGTP, dTTP), $1 \mathrm{U}$ of Taq DNA polymerase and PCR buffer [75mMol Tris- $\mathrm{HCl}$ pH 9.0, 50m Mol KCl, 2m Mol MgCl2 and $20 \mathrm{~m} \mathrm{Mol}(\mathrm{NH} 4) 2 \mathrm{SO} 4]$ to make up the volume. DNA amplification was carried out using light cycler instrument.

The amplification protocol was as follows: Initial denaturation step at $95^{\circ} \mathrm{C}$ for $5 \mathrm{~min}, 30$ cycles at $95^{\circ} \mathrm{C}$ for 30 sec and $30 \mathrm{sec}$ at $57^{\circ} \mathrm{C}$ annealing temperature and at $72^{\circ} \mathrm{C}$ for $45 \mathrm{sec}$. The final extension step was performed at $72^{\circ} \mathrm{C}$ and was carried out using light cycler instrument. The $200 \mathrm{bp}$ PCR product was digested 3 hours with $2 U$ of the restriction enzyme Satl (Fermentas, Vilnius, Lithuania). The Cys allele was digested into $100 \mathrm{bp}$ fragments whereas the Ser variant remained intact.

Data were coded and entered using the statistical package SPSS version 23. Data was summarized using mean and standard deviation for quantitative variables and frequencies (number of cases) and relative frequencies (percentages) for categorical variables. Comparisons between groups were done using unpaired t test [11].

\section{Results}

Characteristics of the study subjects. The characteristics of 240 patients with larynx cancer and 240 controls are presented in Table 1. Overall, there was no a statistically significant difference between the cases and controls in the distribution of age or gender while as regards to smoking status, there was a statistically significant difference in patients group when compared to control group ( $p$ value $<0.05$ ). The frequency of moderate and heavy smokers was higher in the patients (32.9\% and $56.7 \%$, respectively) than in the controls (14.6 and $9.6 \%)$ ( $p<0.001$ in both cases).

Table 1. The characteristics of larynx cancer in patients and controls

\begin{tabular}{|l|c|c|c|}
\hline \multicolumn{1}{|c|}{ Characteristic } & $\begin{array}{c}\text { Controls } \\
n=240(100 \%)\end{array}$ & $\begin{array}{c}\text { Patients } \\
n=240(100 \%)\end{array}$ & $p$ value \\
\hline Sex & $197(82 \%)$ & $192(80 \%)$ & \\
\hline Male & $43(18 \%)$ & $48(20 \%)$ & $0.816^{\mathrm{a}}$ \\
\hline Female & 63 & 64 & \\
\hline Age & $64.9 \pm 8.8$ & $63.9 \pm 8.4$ & \\
\hline Median & $50-83$ & $46-82$ & $0.558^{\mathrm{b}}$ \\
\hline Mean \pm S.D. & \multicolumn{5}{|l}{} \\
\hline Range & $80(33.3 \%)$ & $8(3.4 \%)$ & \\
\hline Tobacco smoking & $102(42.5 \%)$ & $17(7 \%)$ & \\
\hline Never & $35(14,6 \%)$ & $79(32.9 \%)$ & \\
\hline Former & $23(9.6 \%)$ & $136(56.7 \%)$ & $<0.001^{\mathrm{C}}$ \\
\hline Moderate &
\end{tabular}

a: $c^{2}$ test

b: Mann-Whitney U test

c: logistic regression adjusted for sex, age and smoking

\section{Association between hOGGı Ser326Cys polymorphism and larynx cancer}

The observed genotypes and allele frequencies of hOGG1among cases and controls and their associations with 
risk of cancer larynx in this work were demonstrated in Table 2. There were $139(58 \%)$ patients with ser/ser genotype, 79(32.9\%) patients with ser/cys genotype and 22(9.1\%) patients with cys/cys genotype, while in control group $213(89 \%)$ subjects were with ser/ser genotype, 22 (9\%) with ser/cys genotype and 5(2\%) with cys/cys genotype. There was aa statistically significant difference between patients and control groups as regard Ser/Ser, Ser/Cys, Cys/Cys and (Ser/ Cys + Cys/Cys) genotypes of the hOGG1 gene (Pvalue $<0.05$ ). Moreover, there was a stronge association for the Ser/Cys heterozygotes than Cys/Cys homozygotes with larynx cancer.

Table 2. Association between hOGG1 polymorphism and larynxcancerin patients and control groups

\begin{tabular}{|l|c|c|c|c|c|c|}
\hline \multicolumn{1}{|c|}{ Genotypes } & \multicolumn{2}{c|}{$\begin{array}{c}\text { Patients } \\
N=240 \%\end{array}$} & \multicolumn{2}{c|}{$\begin{array}{c}\text { Control } \\
N=240 \%\end{array}$} & \multicolumn{2}{c|}{$\begin{array}{c}\text { Chi-square } \\
\text { X2 p-value }\end{array}$} \\
\hline Ser/Ser & 139 & 58 & 213 & 89 & 1.465 & 0.021 \\
\hline Ser/Cys & 79 & 32.9 & 22 & 9 & 1.888 & 0.028 \\
\hline Cys/Cys & 22 & 9.1 & 5 & 2 & 1.667 & 0.017 \\
\hline Ser/cys + Cys/Cys & 101 & 42 & 27 & 11 & 1.445 & 0.001 \\
\hline
\end{tabular}

The association between smoking asa risk for larynx cancer and genotypes of hOGG1 gene polymorphism wasdemonstrated inTable 3 . This study revealed that the Ser326Cys polymorphism was increased in patients with cancer larynx in bothmoderate and heavy smokers but had more potentiated effect in heavy smokers. So, this Cys allele of the Ser326Cys polymorphism increased the risk of larynx cancer in both moderate and heavy smokers.

Table 3. Association between the genotypes of hOGG1 gene polymorphism and smoking as a risk of cancer larynx in different groups

\begin{tabular}{|c|c|c|c|c|c|c|c|c|c|}
\hline Genotype & \multicolumn{2}{|c|}{ Former smokers } & \multicolumn{3}{|c|}{ Moderate smokers } & \multicolumn{3}{c|}{ Heavy smokers } \\
\hline & Patients & Controls & $\begin{array}{c}\text { aX2 } \\
P\end{array}$ & Patients & Controls & $\begin{array}{c}\text { aX2 } \\
P\end{array}$ & Patients & Controls & $\begin{array}{c}\text { aX2 } \\
P\end{array}$ \\
\hline Ser/Ser & 17 & 102 & $\begin{array}{c}4.276 \\
0.162\end{array}$ & 57 & 28 & $\begin{array}{c}3.24 \\
0.241\end{array}$ & 57 & 3 & $\begin{array}{c}1.345 \\
0.001\end{array}$ \\
\hline Ser/Cys & 0 & 0 & --- & 20 & 7 & $\begin{array}{c}1.324 \\
0.031\end{array}$ & 59 & 15 & $\begin{array}{c}2.312 \\
0.01\end{array}$ \\
\hline Cys/Cys & 0 & 0 & --- & 2 & 0 & $\begin{array}{c}1.322 \\
0.011\end{array}$ & 20 & 5 & $\begin{array}{c}1.121 \\
0.021\end{array}$ \\
\hline $\begin{array}{c}\text { Ser/cys + } \\
\text { Cys/Cys }\end{array}$ & 0 & 0 & --- & 22 & 7 & $\begin{array}{c}1.022 \\
0.041\end{array}$ & 79 & 20 & $\begin{array}{c}1.873 \\
0.00\end{array}$ \\
\hline
\end{tabular}

a: $\chi^{2}$ test $p$ - value

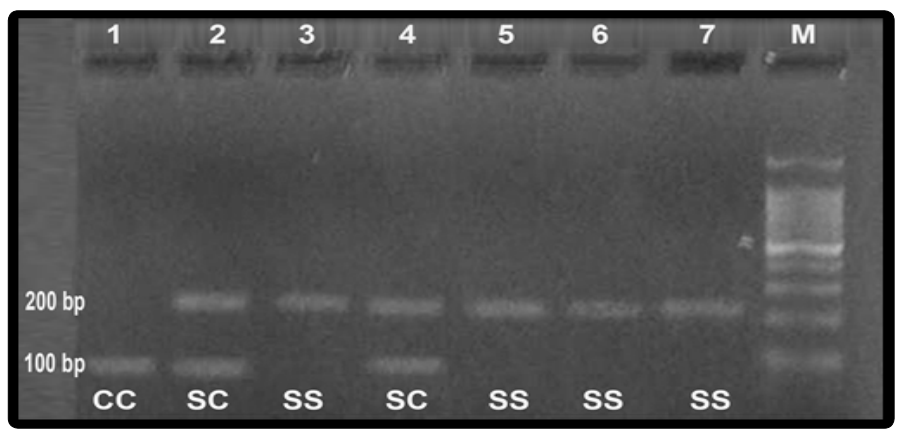

Figure 1. Representative restriction fragment length polymorphismpolymerase chain reaction (RFLP-PCR) analysis of the Ser326Cys polymorphism of the DNA repair hOGG1 gene. Lane M, DNA marker. Lane 3, 5, 6 and 7: the Ser326Ser homozygote (SS) has not been cleaved by the Satl enzyme and remains a single 200-bp band, lane 1 Cys326Cys homozygote (CC) has been cleaved by Satl and yields a 100-bp band, lane 2 and 4 the Ser326Cys heterozygote (SC) contains both bands (200 and $100 \mathrm{bp}$ ) following restriction digestion.

\section{Discussion}

DNA repair process play an important role in stability of the genome and their adequate functioning could prevent cancer development. The hOGG1 proteinis a line of the cellular defense against oxidative DNA damage, so any change in the gene encoding this protein may influence the ability of the cell to eliminate the oxidative DNA damage.

Cancer larynx is often smoke-related so, this study aimed to investigate the association of the variability in thehOGG1 genepolymorphism, and there is k of larynx cancer in Egyptian patients.

In this study, statistical analysis suggested that tobacco smoking consumption is a risk factor for development of larynx cancer. Heavy smokers had a much higher risk ratio than former and moderate smokers' groups, which displayed a higher risk than never- smokers. This was agreed with results of other authors and researchers $[12,13]$.

A link between 8-oxoG formation and tobacco smoke carcinogenesis has also been suggested with a correlation observed between levels of 8-oxoG and the number of cigarettes smoked. In addition, increased levels of 8-oxoG were detected in both peripheral leukocyte DNA and the nuclei of oral mucosa from smokers as compared to nonsmokers. Furthermore, a $50 \%$ increase in the levels of 8-oxoG was detected in the urine of smokers as compared with the urine of non-smokers [14].

These data strongly implicate 8-oxoG formation in tobacco smoke-induced carcinogenic pathways. These data are also consistent with the fact that $G>T$ a transversions, which are the primary mutational event induced by 8 -oxoG, are also the primary mutational event occurring in the $p 53$ tumor suppressor gene, a common occurrence for upper aero digestive tract cancers [9].

In this study, there was a significant difference between patients and control groups as regard the genotypes of the hOGG1 where, Ser/Ser $89 \%$, Ser/Cys $9 \%$, and Cys/Cys $2 \%$ in the controls and those in patients were $58 \%, 32.9 \%$ and $9.1 \%$, respectively. The role of the Ser-326Cys SNP and HNC risk was investigated in six studies [15]. The first case-control study, with a small sample size (167 cases and 331 controls), reported a positive association with HNC risk [9], which was confirmed by Pawlowska et al. [6]. Moreover, Sliwinski et al. [16] showed that the Ser326Cys SNP might modify the risk of SCCHN associated with smoking.

Pawlowska et al. [6] searched for an association between the Ser326Cys polymorphism and the risk of larynx cancer in a Polish population and studied also the association between genotypes of this polymorphism and smoking-related cancers. They concluded that the Cys326 allele of the hOGG1 gene may increase the risk of larynx cancer associated with smoking or alcohol. Cys326 allele had a potential effect in the group of heavy smokers. However, this allele did not affect the groups of former and moderate smokers. These differences may be due to small sample size [6]. 


\section{Conclusion}

From this study it could be concluded that the Ser/Cys and Cys/Cys genotypes are significantly associated with the increased risk of larynx cancer in Egyptian population.

\section{Acknowledgements}

- To Clinical Pathology Department, Faculty of Medicine, Egypt.

- The authors declare that they have no competing interests.

\section{References}

1. Chadha S, Gupta B, Jatwani S, Gulati A. A study of patient factors and tumor characteristics in malignancy of larynx: A tertiary care center experience. J Laryngology and Voice. 2011; (2): 79-80.

2. Hamid OA, El Fiky LM, Medani MM, AbdelHady AN, Ali HH. Laryngeal Cancer In Egypt: Quality Of Life Measurement With Different Treatment Modalities. Head and Neck. 2010; 33(8): 1162-1169. doi: 10.1002/ hed.21591

3. ElZawahry IM, AbdulHady E, Mosalumc HS, El NT, Salama DH. Changes in Survival in Locally Advanced Laryngeal Carcinoma Over Past Three Decades. Arab Journal of Nuclear Science and Applications. 2013; 46(4): 312-321.

4. ValkoM, RhodesCJ, MoncolJ, Izakovic M, Mazur M. Freeradicals, metals and antioxidants in oxidative stress-induced cancer. Chem. Biol. Interact. 2006; 160: 1-40. doi: 10.1016/j.cbi.2005.12.009

5. Kuznetsov NA, Koval VV, Fedorova OS. Mechanism of recognition and repair of damaged DNA by human 8-oxoguanine DNA glycosylase hOGG1. Biochemistry (Moscw). 2011; 76(1): 118-30.

6. Pawlowska E, Janik-Papis K, Rydzanicz M, Zuk K, Kaczmarczyk D, et al. The Cys326 allele of the 8-oxoguanine DNA N- glycosylase 1 gene as a risk factor in smoking- and drinking-associated larynx cancer. Tohoku J. Exp. Med. 2009; 219(4): 269-75.
7. Vassallo R, Kroening PR, Parambil J, Kita H. Nicotine and oxidative cigarette smoke constituents induce immune-modulatory and proinflammatory dendritic cell responses. Mol. Immunol. 2008; 45: 3321-9. doi: 10.1016/j.molimm.2008.04.014

8. Carina L, Susana V, Mário P, Elisabete C, Manuel G, et al. Relation between DNA damage measured by comet assay and OGG1 Ser326Cys polymorphism in antineoplastic drugs biomonitoring. Frontiers. 2015; 2(3): 204-218.

9. Elahi A, Zheng Z, Park J, Eyring K, McCaffrey T, et al. The human OGG1 DNA repair enzyme and its association with or laryngeal cancer risk. Carcinogenesis. 2002; 23: 1229-34.

10. Hashimoto T, Uchida K, Okayama N, Imate $Y$, SuehiroY, et al. Interaction of OGG1Ser326Cys polymorphism with cigarette smoking in head and neck squamous cell carcinoma. Mol. Carcinog. 2006; 45: 344-348. doi: $10.1002 / m c .20140$

11. Chan YH. Biostatistics102: Quantitative Data-Parametric and Nonparametric Tests. Singapore Med J. 2003; 44(8): 391-396.

12. DeStefani $E$, Boffetta $P$, Deneo-Pellegrini $H$, Ronco AL, Acosta $G$, et al. The effect of smoking and drinking in oral and pharyngeal cancers a casecontrol study in Uruguay. Cancer Lett. 2007; 246: 282-289.

13. Jun L, Xiao-Lin C, Zhen Z, Da-Peng L, Tong J, et al. HOGG1 Ser326Cys Polymorphism and Susceptibility to Head and Neck Cancer: A Metaanalysis. Asian Pacific J Cancer Prev. 2011; 12(10): 2491-2494.

14. Romano G, Sgambato A, Flamini G, Boninsegna A, Milito S, et al. Evaluation of 8-hydroxydeoxyguanosine in human oral cells: the importance of tobacco smoke and urban environment. Anticancer Res. 2000; 20: 38043806.

15. Wang $\mathrm{M}, \mathrm{Chu} \mathrm{H}$, Zhang Z, Wei Q. Molecular epidemiology of DNA repair gene polymorphisms and head and neck cancer. The Journal of Biomedical Research. 2013; 27(3): 179-192. doi: 10.7555/JBR.27.20130034

16. Sliwinski T, Przybylowska K, Markiewicz L, Rusin P, Pietruszewska W, H et al. Mutyh Tyr165Cys, OGG1 Ser326Cys and XPD Lys- 751Gln polymorphisms and head neck cancer susceptibility: a case control study. Mol Biol Rep. 2011; 38: 1251- 61. doi: 10.1007/s11033-010-0224-x 